\title{
Criminal Law Protection of Property: A Comparative Critique of the Offences of Stealing and Theft in Nigeria
}

\author{
Timothy F. Yerima, \\ Senior Lecturer and Acting Dean \\ Faculty of Law, Kogi State University Anyigba, Nigeria \\ E-mail: tfyerimah1@yahoo.com \\ Olubayo Oluduro, \\ Senior Lecturer, Faculty of Law \\ Adekunle Ajasin University, Akungba-Akoko, Ondo State, Nigeria \\ E-mail: olubayooluduro@yahoo.com
}

Received: April 6, 2011

Accepted: October 9, $2011 \quad$ Published: March 1, 2012

doi:10.5539/jpl.v5n1p167

URL: http://dx.doi.org/10.5539/jpl.v5n1p167

\begin{abstract}
This article considers criminal law protection of property in Nigeria with particular focus on the offences of stealing and theft under the Criminal Code and Penal Code applicable in Southern and Northern Nigeria respectively. A comparative analysis and critique of the features of the offences under the two Codes are clearly spelt out. The English Theft Act, 1968 as amended by the Criminal Justice Act, 1991 and Penal Legislation of other jurisdictions are utilized for comparative analysis with a view to pointing out some loopholes and lacunas in the Criminal Code and the Penal Code with particular regard to the two offences. At the tail of the article, the writers proffered suggestions for the way forward and the need for legislative intervention to redraft some of the provisions of the two Codes dealing with stealing and theft.
\end{abstract}

Keywords: Criminal Code, Dishonest intention, Fraudulent conversion, Fraudulent taking, Moveable property, Penal Code, Stealing, Theft

\section{Introduction}

Property has been regarded as the second most important possession of man next to life (Note 1). This is evident in the successive constitutions of Nigeria, which leave no stone unturned in exonerating a person who kills in the protection of his property or someone's property. Section 33 (2) of the 1999 Constitution of the Federal Republic of Nigeria, for example, does not regard death resulting from the use of reasonable force for the defence of property as a violation of the right to life guaranteed by the constitution (Note 2). Defence of property is also allowed under the Criminal Code (Note 3) and the Penal Code (Note 4). Section 289 of the Criminal Code provides that: "It is lawful for any person who is in peaceful possession of any movable property and for any person acting by his authority to use such force as is reasonably necessary in order to resist the taking of such property by a trespasser or in order to retake it from a trespasser".

While under this section a person is prohibited from inflicting harm, section 282 permits a person to cause death in the defence of property, particularly dwelling house (Note 5). Section 60(b) of the Penal Code also provides that: "Every person has a right ... to defend ... the property whether movable or immovable of himself or any other person against any act which is an offence falling under the definition of theft, robbery, mischief, or criminal trespass or which is an attempt to commit theft, robbery, mischief or criminal trespass (Note 6)".

Although, the foregoing rights are restricted to some extent, (Note 7) the general provision remains that killing a person in defence of one's property or someone's property is a complete defence known in the Nigerian criminal law as the right to defence of property (Note 8).

Also, the right to acquire and own movable property and interest in immovable property is guaranteed by the Constitution of Nigeria (Note 9) as well as regional (Note 10) and international human rights instruments (Note 11). Property is, therefore, protected by common law, human rights and criminal law. It is, however, apposite to reveal, 
before delving into the crux of the article that apart from the offences of stealing and theft, there are other offences against property under the Criminal Code, Penal Code and other legislation in Nigeria, including, the offences of receiving stolen property and, unlawful possession of thing reasonably suspected of having been stolen (Note 12), robbery (Note 13), burglary and house breaking (Note 14), cheating (Note 15), extortion (Note 16), criminal misappropriation (Note 17), corruption (Note 18), et cetera. Although, these offences are outside the scope of this research, reference would be made to them where necessary.

\section{Nature and Meaning of Stealing and Theft}

It is not within the scope of this article to dabble into the history of stealing and theft but it is very important to reveal that even before God passed the Ten Commandments (Note 19), including "Thou shall not steal" (Note 20), the act of stealing had been contemplated. For example, it was asked in the Book of Genesis: "What do you mean by stealing my master's personal silver drinking cup, which he uses to predict the future? What a wicked thing you have done" (Note 21). Even when "thou shall not steal" was still relatively fresh in the minds of Israelites some of them were still stealing. As it was asked: "Didn't God punish all the people of Israel when Achan, a member of the clan of Zerah, sinned by stealing the things set apart for the LORD? He was not the only one who died because of that sin" (Note 22). That is how the act of stealing continued on and on (Note 23). That the acts of stealing and theft have long been criminalized in the penal legislation of various States juxtaposes the interplay between law and religion (Note 24).

Black's Law Dictionary defines the word "steal" as: "1.To take (personal property) illegally with the intent to keep it unlawfully. 2. To take (something) by larceny, embezzlement, or false pretences (Note 25)." Section 390 of the Criminal Code creates the offence of stealing by providing, inter alia: that "Any person who steals anything capable of being stolen is guilty of a felony ... (Note 26)," Section 383 (1) of the same Code clears the dust on what constitutes stealing. Thus, "A person who fraudulently takes anything capable of being stolen, or fraudulently converts to his own use or to the use of any other person, anything capable of being stolen, is said to steal that thing (Note 27)". In Ajiboye v. The State (Note 28), Kalgo JCA (as he then was), reiterate this definition with respect to stealing money in an explanatory words: "Under section 383(1) of the Criminal Code, the fraudulent taking of money from someone is stealing and the fraudulent conversion of money to the use of the taker or to the use of any other person is also stealing. What is essential in both cases is that the taking or the conversion must be fraudulent".

Indeed to a layman in the field of law, the offences of stealing and theft used under the Criminal Code and Penal Code respectively are the same; and the different words used is a matter of nomenclature. This is misleading. It is gratifying to note that what has been used broadly as stealing under the Criminal Code is used narrowly as "theft" under the Penal Code. A perusal of the provision of section 286 of the Penal Code reveals that the differences between the two offences go beyond nomenclature. The section provides that: "Whoever intends to take dishonestly any movable property out of the possession of any person without that person's consent moves the property in order to take it is said to commit theft".

It is also an offence of theft under section 286 (2) of the Penal Code to dishonestly abstract, divert, consume or use any electricity or electric current. This law can be distinguished from the principle under the English Criminal Law, where judicial authority has established that electricity cannot be stolen (Note 29). But there is the specific offence of abstracting electricity under section 13 of the English Theft Act, 1968 which is punishable for a term not exceeding five years imprisonment (Note 30). The offence can be committed even if the meter is not tampered with (Note 31). In any case, Omage JCA clearly summarized the vital elements of the offence of theft in Mohammed v. The State (Note 32), as: absence of consent of the owner of the movable property; movement of the said property; and intention to take the movable property.

A scholar also attempted some distinctions between stealing and theft in the Criminal Code and Penal Code respectively as follows:

(a) Penal Code shifts the emphasis to what or who could be the object of stealing from ownership to possession;

(b) The Penal Code avoids the style of differentiating between animated or inanimate objects; and

(c) There is no corresponding offence of child stealing under the Penal Code - all objects of theft may be artificial or natural things but not including a human being (Note 33).

In terms of nomenclature, the English Theft Act 1968, like the Penal Code of Northern Nigeria uses the word "theft" not "stealing". Section 1 provides that: "A person is guilty of theft if he dishonestly appropriates property belonging to another with the intention of permanently depriving the other of it (Note 34)".

There is no disputing the fact that by the use of the words "dishonestly appropriates" and "permanently depriving" 
under section 1 of the English Theft Act, this Statute combines the definition of theft under section 286 of the Penal Code and section 383 of the Criminal Code respectively. It is, therefore, not surprising that some dictionaries compiled by English writers do not distinguish between stealing and theft (Note 35).

\section{Features of "Things Capable of Being Stolen" or Subject of Theft}

To amount to stealing or theft under section 383 of the Criminal Code, and section 286 of the Penal Code respectively, the thing taken (or converted (Note 36)) must be capable of being stolen or capable of being subject of theft; it must have the following features: ownership or possession, value, it must be a movable property and generally the taking must be without the owner's consent. While some of these features are expressly stated, others are implied; and they are considered hereunder seriatim.

\subsection{Ownership or Possession}

Neither the Criminal Code nor the Penal Code uses the word "ownership". And while the Penal Code uses the word "possession", the Criminal Code omitted the word. Despite this omission, however, it is well settled that anything capable of being stolen must have owner or must be under someone's possession. Justice Niki Tobi JCA (as he then was) in Onagoruwa v. State (Note 37), stated the significance of ownership in the offence of stealing, where he stated, inter alia that: "Ownership is a most vital and indispensable essential or ingredient of the offence of stealing. It is the ownership upon which all other essentials or ingredients stand. It is the baseline of the offence of stealing". Consequently, anything which has no owner cannot possess the quality of being stolen. That is why Justice Niki Tobi continued in Onagoruwa v. The State, (Note 38) that: "Before an accused could be convicted of the offence of stealing property, there must be evidence that the property is owned by a person, the person could be a natural person or an artificial person ... but the property must be owned or capable of being owned". It is due to the significance of this ingredient that as a matter of procedure in the offence of stealing, the Particular of Offence must reveal the name of the owner of the property. In a charge of stealing, therefore, proof that the property stolen belongs to some person is not only an essential ingredient of the offence but also the duty of the prosecution to adduce that evidence (Note 39). The legal consequence of this is that a property without owner cannot be capable of being stolen. A thing may be ownerless, for example, because it is incapable of being owned at all or it is abandoned. Thus, where an accused/appellant removed and used some corrugated iron sheets abandoned by Government and some years later, he was arrested, prosecuted and convicted of stealing the property, his conviction was quashed on appeal (Note 41). The Court reasoned that the taking of property abandoned by its owner is not the taking of property capable of being stolen. But the question that comes to the fore is: at what stage property will be regarded as being abandoned. It seems this will depend on the nature and value of the property as well as all the circumstances of each case.

In any case, the foregoing principle should not be misinterpreted as meaning that an accused person cannot be guilty of stealing or theft where stolen property cannot be recovered. The fact that the stolen property cannot be recovered does not mean that the property had no owner. It is a settled law that the prosecution can prove a charge of stealing either by direct or circumstantial evidence even if the stolen property is not recovered. But before the accused person can be convicted in such circumstances, there must be evidence as to the commission of the crime which will leave no ground for reasonable doubt (Note 42). Where, therefore, the police officer who investigated a case did not turn up to give evidence on whether he recovered any item or not and the evidence of Prosecution Witness 2 (PW2) and Prosecution Witness 3 (PW3) were not credible and positive, the conviction of the accused for the offence of stealing was quashed (Note 43).

The word "owner", according to Justice E. O. Fakayode, "is used in a limited sense for the purpose of the law which is essentially an offence against possession (Note 44)". Possession in this context deals with physical control of the thing owned. But there can be ownership without possession (Note 45). Since stealing or theft is an offence against possession, not ownership, it goes to show that a person can steal a thing from either the owner or his servant or agent. Conversely, an owner of property can steal the thing in possession of a person who has limited or special interest in it. Persons who have special interest in a property include a pledgee, trustee or bailee (Note 46).

It is explicit from the foregoing analysis that both ownership and possession are essential features and elements of stealing and theft. It is not surprising, therefore, that, though section 1(1) of the English Theft Act does not use the word "possession" or "ownership," section 5(1) of the Act clears the dust by defining the phrase "property belongs to another". It states: "Property shall be regarded as belonging to any person having possession or control of it or having in it any proprietary right or interest (Note 47)". No doubt, the words "any proprietary right" refers to the right of the person who is not the owner but has possession and control of the property.

\subsection{Movable Property}


Anything capable of being stolen must be a movable property. Immovable property cannot be stolen. This is a feature expressly stated in section 286 of the Penal Code and implied by the phrase: "capable of being stolen" under sections 383(1) and 390 of the Criminal Code. Unfortunately, the two Codes do not provide exception(s) to this provision, leaving a lacuna as to whether a person who is given money to buy a land and indeed he bought the land but later converted it to his own use, will be liable for stealing the land or the money. This loophole in the Nigerian criminal legislation was discovered in Robinson Ojoko v. Inspector General of Police (Note 48), where the accused/appellant was given money to buy a piece of land in the name of the financier. He indeed bought the land, but conveyed it unto himself instead of the owner of the money. The appellate Court acquitted him on the charge of stealing, stating that the appellant did not steal the money since it was given to him with the full consent of the owner and he applied it to purchase the land as was directed. It was further held that the accused converting the land to himself could not amount to theft since land cannot be stolen. Though the case was decided in the mid-50s, it still generates heated debates among scholars in Nigeria. Professor Sufyan Chukkol asked: “... did the accused not use the money 'at his will' to make him liable under section 383 (2)(f) of the Criminal Code? (Note 49)" Peter Ocheme concluded that the appellant had committed the offence of cheating (Note 50).

"Property," according to Sepulveda M. et al, is: “... those material things which can be possessed, as well as any right which may be part of a person's patrimony; that concept includes all movables and immovables, corporeal and incorporeal elements and any other intangible object capable of having value (Note 51)". It is noteworthy that the Criminal Code does not define the word "property". Section 1, however, says that property "includes everything, animate or inanimate, capable of being the subject of ownership" or capable of being stolen. The word "inanimate" include "a thing in action (or chose) in action (Note 52). To that extent, the Criminal Code can be compared with the English Theft Act, 1968 and the Crimes Act of Victoria, Australia, 1958, which state that property "includes money and all other property, real or personal, including things in action and other intangible property (Note 53)". In Torkington v. Magee (Note 54), Channel J. defined "chose (thing) in action" as: "All personal rights of property which can only be claimed or enforced (taking legal) action and not by taking physical possession". In Chan Man Sin v. R. (Note 55), Lord Oliver of Aylmerton said: “... it is not disputed that the debt due to the customer from his banker is a chose in action capable of being stolen and this equally applies to the sum which a customer is entitled to overdraw under contractual arrangements which he has made with the bank". Judicial authorities have, however, shown that the meaning of property under the English Theft Act and Crimes Act of Victoria, Australia does not extend to all intangible property such as confidential information (Note 56) and trade secrets (Note 57). It is submitted that these principles, though persuasive, are good laws in Nigeria.

Section 12 of the Penal Code also provides that "the words movable property include corporeal property of every description except land and things attached to the earth or permanently fastened to anything which is attached to the earth". The word "animate" capable of being stolen includes animals, for example, stealing of cattle (Note 58) and even human being (Note 59).

Distilled from the foregoing comparison is the fact that under both Criminal Code and Penal Code, unlike the English Theft Act (Note 60), land is not a property capable of being stolen. Also, things permanently attached to land are not capable of being stolen. But those things that are severed, and, therefore, cease to be so attached can be stolen. Where a person, for instance, enters cashew farm and plucked off and carry away some cashew fruits for his use, it amounts to stealing or theft. To prevent the occurrence of the problem arising from cases like Robinson Ojoko v. Inspector General of Police (Note 61), the English Theft Act, 1968, provides three exceptions to the rule that land is incapable of being stolen. These exceptions are:

(i)

where a trustee or personal representative or a person authorized by Power of Attorney or liquidator of a company, who is to sell or dispose of land belonging to another, appropriates the land or anything forming part of the land in breach of the confidence reposed in him. Thus, although this provision uses the word "sell" not "buy," it is submitted that if Robinson Ojoko v. Inspector General of Police (Note 62), had been decided under the English law, the appellant would have been convicted of stealing the land.

(ii) Where a person who is not in possession of the land appropriates anything forming part of the land by severing it or causing to be severed (Note 63).

(iii) Where a person in possession of the land as tenant appropriates the whole or part of any fixture or structure let to be used with the land (Note 64).

Notwithstanding the loopholes in the Nigerian penal legislation regarding stealing and theft, the movable property capable of being stolen must be in existence. A person cannot steal what is not in existence. According to Niki Tobi JCA (as he then was), in Onagoruwa v. The State (Note 65) "A person can only be charged with stealing what is in 
existence. Therefore, before a Court of law can convict an accused person for stealing, the prosecution must prove the existence of the thing allegedly stolen".

\section{The Debate of Whether "Dead body" is Capable of Being Stolen}

One issue that has generated controversies among scholars is whether "dead body" is capable of being stolen. This imperative question is better tackled from the question whether dead body is a property within the meaning of property in the Nigerian criminal law. According to Halbury's Laws of England, "the law in general recognizes no property in a dead body" (Note 66). In the words of Sir James Stephen: "The dead body of human being is not capable of being stolen;" and Salmon stated: "A corpse is the property of no one, it cannot be disposed-off by will or other instrument and wrongful dealings with it cannot amount to theft. The law, however, secures decent burial for all dead men and the violation of it is a grave offence" (Note 67).

It seems the foregoing authorities followed the decision in R. v. Sharpe (Note 68), where it was stated, inter alia, that "Our law recognizes no property in a corpse, and the protection of the grave at common law as contradistinguished from ecclesiastic protection to consecrated ground depends on this form of indictment".

However, in Dobson v. North Tyneside Health Authority (Note 69), English Court noted, inter alia: "Parts of a corpse are capable of being property within section 4 of the Theft Act, if they have acquired different attributes by virtue of the application of skill, such as dissection or preservation techniques, for exhibition or teaching purposes". The decisions of the Court in the foregoing cases were reiterated and reaffirmed in a more recent case of $R$. v. Kelly (Note 70), where the Court stated, inter alia that: "If that principle is now to be changed, in our view, it must be by parliament, because it has been express or implicit in all the subsequent authorities and writings to which we have been referred that a corpse or part of it cannot be stolen. To address the point as it was addressed before the trial judge and to which his certificate relates, in our judgment, parts of a corpse are capable of being property within section 4 of the Theft Act 1968 if they have acquired different attributes by virtue of the application of skill, such as dissection or preservation techniques, for exhibition or teaching purposes".

In Nigeria, the law on the issue of whether dead body is capable of being stolen is not clear. In the words of Okonkwo and Naish: "... a corpse may possess such peculiar attributes as to justify its preservation on scientific or other grounds. If, therefore, a person has performed some work of skills on such a corpse in his lawful possession, it may be stealing to dispossess him of it (Note 71)". The authors seem to have relied on the English case of Doodeward v. Spence (Note 72), as reiterated in Dobson v. North Tyneside Health Authority (Note 73). The authors, however, ignored to consider some provisions of the Criminal Code. Section 242, for example, provides, inter alia: "Any person who ... improperly or indecently interferes with, or offers any indignity to, any dead human body or human remains whether buried or not, eats or receives for the purpose of eating any part of a dead human body is guilty of a misdemeanor and is liable to imprisonment for two years".

Section 218 of the Penal Code provides similarly that it is an offence to knowingly eat or receive for the purpose of eating any part of human corpse (Note 74). It is also an offence under the Penal Code for a person to receive or has in possession a human head or skull as trophy, juju or charm (Note 75). Although, the foregoing provisions do not expressly state that corpse or any part of it is a property capable of being stolen, it is glaring that dealing with corpse improperly, indecently or offering any indignity to dead human body is an offence under the Criminal Code and Penal Code. It is necessary to recast that under section 382 of the Criminal Code, every inanimate thing (not alive), which is the property of another person and which is movable, is capable of being stolen. It is doubtful if the phrase "inanimate thing" does not include "dead body". The word "movable" should not be misconstrued to mean that the thing must be alive. It simply means that the thing can be moved.

\section{Re- Evaluating the Actus Reus of Stealing}

Under section 383 of the Criminal Code, the actus reus of stealing may occur either by taking or converting the "thing" capable of being stolen (Note 76). Under section 286 of the Penal Code, the actus reus of theft is "moving (in order) to take someone's possession without his consent" (Note 77).

\subsection{The Taking}

The "act of taking" as an actus reus of stealing does not necessarily require the thief to take the property completely to his physical possession. It suffices if he merely moves it or causes it to move. What section 383(6) requires is mere movement of the thing stolen. The position is the same under the Criminal Code and the Penal Code. It is the principle in the English case of $R$. v. Taylor (Note 78) that is incorporated in the Nigerian penal legislation. In the hypothetical illustration of Okonkwo and Naish: “... if A intending to steal a book from B's brief case begins to take out the book whereupon B suddenly shouts at him and he drops it back into the brief case, A's conduct amounts to stealing and not merely an attempt to steal" (Note 79). However, according to Justice E.O. Fakayode, the foregoing 
hypothetical case might either be stealing or an attempt to steal" (Note 80).

In any case, what is important is whether the accused intend to permanently deprive the owner of the property or the person in possession of the property of it. The taking under section 286 of the Penal Code means depriving someone's possession of the property; not necessarily the owner's possession but any person who possess the thing. This is the principle in the English cases of $R$. v. Turner (Note 81) and $R$. v. Bonner (Note 82). In the Nigerian case of Commissioner of Police v. Nangbo (Note 83), Bate CJ, stated that theft is an offence against possession and that a person already in possession of goods could not commit theft of it. He can, however, commit the offence of criminal breach of trust under sections 311 and 312 of the Penal Code in respect of the goods in his possession.

\subsection{The Act of Conversion}

This is one of the areas that give the offence of stealing under the Criminal Code a wider scope than the offence theft under the Penal Code. Section 383(1) is explicit that stealing can also be committed by conversion. The Criminal Code, however, is silence over what constitutes conversion. It has been accepted that the meaning of conversion under common law and section 383 of the Criminal Code are the same. Under common law, conversion is defined as: "A tort committed by a person who deals with chattels not belonging to him in a manner inconsistent with the rights of the owner" (Note 84). In Bryan A. Garner (ed.), conversion is defined in terms of tort and criminal law as: "The wrongful possession or disposition of another's property as if it were one's own; an act or series of acts of willful interference, without lawful justification, with an item or property in a manner inconsistent with another's right whereby that other person is deprived of the use and possession of the property" (Note 85).

Conversion includes such acts as: taking possession, refusing to give up possession upon demand, disposing of the goods to a third person, or destroying them (Note 86). For conversion to amount to stealing, it must be done with one of the fraudulent intents under section 383 (2) of the Criminal Code. In Onwudiwe v. Federal Republic of Nigeria (Note 87), Niki Tobi JCA (as he then was), stated that: "Conversion is both an offence and a tort. Conversion does not have a life of its own in the Criminal Code but is parasitic on the offence of stealing. As a matter of law, the definition of stealing under section 390 of the Criminal Code includes larceny, embezzlement and fraudulent conversion. It is the fraudulent nature that separates it from the tort of conversion" (Note 88).

In Ajiboye v. The State (Note 89), Kalgo JCA stated, with respect to criminal conversion, inter alia:

Dealing with goods in a manner inconsistent with the right of the true owner amounts to a conversion provided that it is also established that there is an intention on the part of the defendant (accused) in so doing to deny the owner's right or to assert a right ... by spending the complainant's money for property other than those intended by the complainant; the appellant has acted in a manner inconsistent with his right. This, therefore, amounts to conversion and it is immaterial whether, as in this case, the thing converted is, at the time of commission, in the possession of the person who converted it.

As it is pointed out, the prosecution has to show that the act of conversion is done for the use of the accused or to the use of any other person. Where, therefore, some money were moved by the accused from one safe to another in the same room, the Court held that no offence was committed, though the two safes from where the act was done belonged to his employer (Note 90).

Also, the fact that the converter had an innocent possession of the property or that he held a Power of Attorney for its disposition or even authority to dispose of the property will not be considered when determining whether a conversion is fraudulent. This provision of the Criminal Code (Note 91) was applied in Oshinye v. Commissioner of Police (Note 93). In that case, the accused, who had no fraudulent intent, obtained some goods from someone under a deceit that the owner had authorized him to take the goods. Later, he appropriated the goods to his own use. Both the High Court and the Federal Supreme Court upheld his conviction by Magistrate Court of stealing by invoking the provision of 383(4) of the Criminal Code. It is submitted that if this case had been decided under the Penal Code, the accused would have been convicted of the offence of criminal misappropriation under section 308 of the Penal Code; and this buttress the fact that the offence of theft under the Penal Code is narrower in scope than the offence of stealing under the Criminal Code of Nigeria.

\subsection{Taking without Consent}

Although, section 383 of the Criminal Code, unlike section 286 of the Penal Code, does not mention the words: "without consent", it is settled that to amount to stealing or theft, the taking must not only be out of someone's possession, but also must be taken "without his consent". It seems many cases decided in Nigeria under the Criminal Code often sink into oblivion the requirement of "absence of consent" as an essential ingredient of stealing (Note 93). It is submitted that the requirement of "absence of consent" is implied under the Criminal Code with regard to 
the offence of stealing. This is because, generally, if the taking or the conversion is done with the consent of the owner, no offence of stealing is committed. In Ejuren v. Commissioner of Police (Note 94), it was held that "absence of consent" or "lack of consent" is implied under section 383 of the Criminal Code. But the consent required is a genuine consent, not consent obtained by threats, intimidation or fraud. The mere keeping of the property, in a manner or place that it is easy for the thief to steal is not tantamount to giving consent (Note 95).

It is also important to reiterate that it is not every taking without consent that amount to stealing or theft. If $\boldsymbol{A}$ picks $\boldsymbol{B}$ 's property under the mistaken belief that it is his, $\boldsymbol{A}$ will not be liable for committing the offence of stealing if he successfully invokes the defence of honest claim of right under section 23 of the Criminal Code (Note 96) or the defence of mistake under section 25 of the Criminal Code, provided at the time of the taking, he was labouring under an honest and reasonable mistake of fact (Note 97). Under the English Theft Act 1968, section 12(6) provides that: "No offence is committed if, at the time of taking, the accused genuinely believed that the owner has consented (or would have consented) to the taking". So, it is for the prosecution to prove the absence of such a belief.

One important distinction between the offence of stealing under the Criminal Code and theft under the Penal Code is that under the latter, the crucial time of lack of consent is the time of the taking. In the hypothetical illustration of Professor Chukkol: "If a hirer of a bicycle later decides to sell it off to pocket the money, his subsequent fraudulent intention to convert the proceeds of the sale will not make him a thief under section 286 of the Penal Code" (Note 98). But this will amount to stealing under section 383 of the Criminal Code. Under the Penal Code, if a person takes someone's property with that person's consent but later converts it to his own benefit (as in the above hypothetical example), or to the benefit of other person, he will be liable for the offence of criminal misappropriation under section 308 (Note 99). That is the reason why it is said that the offence of stealing under the Criminal Code goes beyond the offence of theft under the Penal Code.

\section{Mens Rea in Theft and Stealing}

\subsection{The Mens rea in Theft - Dishonest Intention}

The mental element required to prove the offence of theft under section 286 of the Penal Code is "dishonest intention". That is the "intention to take the movable property (Note 100)". Unlike the English Theft Act (Note 101) that does not define the word "dishonesty", the Penal Code states that: "A person takes property dishonestly, if he takes the thing with the intention of causing a wrongful gain to himself or another or of causing a wrongful loss to any other person (Note 102). "A wrongful gain" is defined as "a gain by unlawful means of property to which the person gaining is not legally entitled" (Note 103). "A wrongful loss" is one which occurs "by unlawful means of property to which the person losing it is legally entitled (Note 104)." Unlike under the Criminal Code, it has been held that the offence of theft under the Penal Code might be committed without the intention to permanently deprive the owner of his property (Note 105).

\subsection{Mens rea in Stealing - Fraudulent Taking or Fraudulent Conversion}

Section 383(1) of the Criminal Code is glaring that for the taking or conversion to constitute the offence of stealing, there must be an element of fraud. In other words, “... the offence of stealing can only ...be committed if the taking of the thing capable of being stolen is done fraudulently (Note 106)." Unlike the Penal Code that defines the word "dishonesty" (Note 107), the Criminal Code omits the definition of "fraudulent". In Onwudiwe v. Federal Republic of Nigeria (Note 108), Niki Tobi JCA (as he then was), said: "A fraudulent action or conduct conveys an element of deceit to obtain some advantage for the owner of the fraudulent action or conduct or another person or to cause loss to any other person. In fraud, there must be a deceit or an intention to deceive flowing from the fraudulent action or conduct to the victim of that action or conduct".

While section 383(1) of the Criminal Code provides that for the taking or conversion to constitute the offence of stealing, there must be an element of fraud, section 383 (2) move further to set out six intents any one of which a person who takes or converts anything capable of being stolen is said to take it or convert it fraudulently. These include: Intention to permanently deprive the owner of the thing of it (Note 109). Thus, intention merely to deprive the owner temporarily does not amount to stealing unless the prosecution proves one of the intents under section 383(2) of the Criminal Code. In Babalola v. The State (Note 110), Karibi-Whyte JSC stated that: "The mens rea of stealing consists of an intention not only to take away the movable property in question from the possession of the owner but also an intention to permanently deprive him of such property;" and in case of money, intention to use it at the will of the person who takes or converts it. The fact that the taker or the converter intends afterwards to repay the amount to the owner is not a defence. In Ajiboye v. The State (Note 111), Kalgo JSC said: "If money is deposited with a person for a special or specific purpose, and it is neither used for that purpose or returned on demand or at a reasonable time thereafter, the provisions of section 383(2)(f) of the Criminal Code will be satisfied and the fraudulent intent required for the offence of stealing will be proved". 
It is gratifying to point out one loophole in the Criminal Code; it does not define the phrase "intention to permanently deprive". Under the English Theft Act, it is clearly stated that: "A person ... is regarded as having the intention of permanently depriving .... if his intention is to treat the thing as his own to dispose of regardless of the other's rights ..." (Note 112). This provision has been interpreted to include "situations where the property is taken on a temporary basis ... so, it goes beyond what might ordinarily be thought of as permanent deprivation (Note 113)." This submission suit the meaning of the phrase "intention to permanently deprive" in section 383 (1) of the Criminal Code because the phrase "is concerned with the defendant's state of mind, not his actions (Note 114)." If the defendant's intentions at the time of the taken or conversion were to take or convert them permanently, his liability is established. What happened afterward is irrelevant. It has also been pointed out that the phrase under the English Theft Act is also "sufficiently flexible to include situations where the property is later returned" but the value of the property has been permanently lost (Note 115). This is the type of "intent" contemplated under section 383 (2) (a) and (e) of the Criminal Code (Note 116). In some jurisdiction, however, intention to deprive the owner of the property temporarily of it is theft. Section 322 of the Criminal Code of Canada is a typical example. It provides that a person steals a thing if he or she takes or converts it fraudulently, without colour of right and with intent to deprive the owner of it, either permanently or temporarily.

\section{Observations and Recommendations}

Efforts have been made in this paper to make a comparative critique of the offences of stealing and theft under the Criminal Code and Penal Code respectively. The features of the two offences have been neatly evaluated. We have observed that what has been regarded as stealing under the Criminal Code has been used narrowly as theft under the Penal Code. Conversely, the offence of criminal misappropriation under the Penal Code is "stealing by conversion" under the Criminal Code. The paper reveals that some ingredients such as ownership, possession and lack of consent are not expressly mentioned under sections 383 and 390 of the Criminal Code that create and define the offence of stealing. It is our submission that these ingredients are implied in these sections. It is maintained that the offence of stealing cannot be committed if these ingredients are lacking. We have, however, pointed out that the offence of stealing can be committed against the person who is not the owner of the property but is in possession of the property.

In consideration of the argument that "dead body" is not a property and, therefore, not capable of being stolen, we have shown that while this argument is accepted with regard to the offence of theft, it is not tenable under the Criminal Code, in view of section 382 of the Code, which makes inanimate thing (not alive) a property capable of being stolen. We have, however, pointed out that under the Criminal Code and Penal Code, dealing with human dead body indecently, improperly or eating any part of dead human body is an offence.

It is also pointed out that the Criminal Code, unlike the English Theft Act 1968, omits the definition of the phrase "intention to permanently deprive". Section 383 (2) of the Code only enumerates different forms of intent.

Lastly, it is observed that there is no need creating the offence of theft and the offence of criminal misappropriation separately as these can be harmonized.

In view of the foregoing observations, we make the following recommendations:

i. There should be incorporated into the Nigerian Criminal Code and Penal Code exceptions pari materia with section 4 (2) of the English Theft Act 1968, to the rule that land is not capable of being stolen. This is to avoid the occurrence of the problem that occurred in Robinson Ojoko v. Inspector General of Police (Note 117).

ii. There is need to define the phrase "anything capable of being stolen" used under the Criminal Code. It is recommended that the phrase "intention to permanently deprive" used under section 383 should also be defined. The definition of the phrase used under section 6 (1) of the English Theft Act 1968 pari materia with section 73 (12) of the Victoria Theft Act 1958 is recommended in this regard.

iii. Although, the phrase "intention of permanently depriving", in the view of writers is interpreted "flexibly to include where the property is taken on a temporary basis", we suggest that in order to avoid the controversy that may arise in the interpretation of the phrase in Nigeria, a provision pari materia with section 322 of the Criminal Code of Canada should be incorporated in the Criminal Code of Nigeria. This will cover situations where the accused intended to deprive the owner of the property of it either permanently or temporarily.

iv. Similarly, although judicial authority has shown that "lack of consent" and "possession," are ingredients of the offence of stealing, these should be clearly brought out in section 390 of the Criminal Code of Nigeria, which creates the offence of stealing. The section should be redrafted to read: "Any person who takes or converts anything capable of being stolen, in possession of another without that other's consent, is guilty of felony..." 
v. The provision of section 383 (2) (e) of the Criminal Code that reads: "an intent to deal with it in such a manner that it cannot be returned in the condition in which it was at the time of taking or conversion," is superfluous in view of the fact that it is covered by section 383 (2) (a) - "An intent permanently to deprive the owner of the thing of it" and should, therefore, be expunged.

vi. The offences of criminal misappropriation and the offence of theft under the Penal Code should be harmonized as the offence of theft or stealing that can be committed by either dishonest taking or dishonest conversion. The harmonization is important in order to avoid duplication of charges.

\section{References}

Aguda A., \& Okagbue I. Principles of Criminal Liability in Nigerian Law (2nd edn., Lagos: Heinemann Educ. Books, 1990), at 305-309.

Aigborhaevbo v. O., \& Stewart N. "Reforming Criminal Code Defences: Self- Defence, Provocation and Defence of Property in Perspective," Ikeja Bar Review, Vol. 2, Pt. 1, Sept. 2007, at 176-178.

Card R. (ed.). Cross \& Jones, Introduction to Criminal Law $9^{\text {th }}$ edn. (London: Butterworths, 1980), at 206.

Chukkol K.S. The Law of Crimes in Nigeria (Zaria: ABU Printing Press, 1988), at 197.

Chukkol, K.S. Defences to Criminal Liability in Nigerian Law: A Critical Appraisal (Zaria: ABU Printing Press, 1983), at 66-76.

Elegido J. M. Jurisprudence (Ibadan: Spectrum Law Publishing, 2000), 367-312.

Eso K. Thoughts on Law and Jurisprudence (Lagos: MIJ Professional Publishers Ltd, 1990), 291- 305.

Fakoyode E.O. The Nigerian Criminal Code Companion (Lagos: Ethiope Publishing Corp., 1985), at 27.

Kalu A.U., \& Osibanjo Y. (eds.). Vol. 12, Perspectives on Human Rights (Lagos: Fed. Min. of Justice, 1992) 97.

Ocheme P. The Nigerian Criminal Law (Kaduna: Liberty Publications Ltd., 2006), at 141-148.

Okonkwo and Naish, Criminal Law in Nigeria (2 $2^{\text {nd }}$ edn., Ibadan : Spectrum Law Series, 2005) at 296.

Olajide-Bello A. "The Defence of Bona Fide Claim of Rights in Nigeria: An Appraisal", Univ. of Ado-Ekiti Law Journal, Vol. 2, 2003, at 28-46.

Onuche E. "An Appraisal of the Right of Private Defence in Nigeria," Kogi State University Bi-Annual Journal of Public Law, Vol. 1, Pt. 1, 2009, at 129-138.

Sepulveda M. et al, Universal and Regional Human Rights Protection: Cases and Commentaries (Ciudad Colon, Costa Rica: Univ. for Peace, 2004), at 375.

\section{Notes}

Note 1. Chukkol K.S., The Law of Crimes in Nigeria, 1988, at 197.

Note 2. See also the Constitution of the Federation (Nigeria), 1963 (1963 Constitution), Art. S.18 (2)(a); The Constitution of the Federal Republic of Nigeria, 1979 (1979 Constitution), S. 30 (2); The Constitution of the Federal Republic of Nigeria, 1999 (1999 Constitution), S. 33 (2)(a).

Note 3. Criminal Code Cap. C38 LFN 2004 (Applicable in Southern and Northern Nigeria respectively).

Note 4. N. R. L. N. 120 of 1960.

Note 5. For comments on the provisions of sections 282 of the Criminal Code in comparison with Chapter 24 of the Swedish Criminal Code, 1973, see Aigborhaevbo V. O. \& Stewart N., "Reforming Criminal Code Defences: SelfDefence, Provocation and Defence of Property in Perspective." Ikeja Bar Review, Vol. 2, Pt. 1, Sept. 2007, at 176-178.

Note 6. For detailed discussion on defence of property, see Chukkol, K.S., Defences to Criminal Liability in Nigerian Law: A Critical Appraisal, 1983, at 66-76; Aguda A. \& Okagbue I., Principles of Criminal Liability in Nigerian Law (2nd edn., Lagos: Heinemann Educ. Books, 1990), at 305-309; Ocheme P., The Nigerian Criminal Law (Kaduna: Liberty Publications Ltd., 2006), at 141-148; Onuche E., "An Appraisal of the Right of Private Defence in Nigeria," Kogi State University Bi-Annual Journal of Public Law, Vol. 1, Pt. 1, 2009, at 129-138. See also Arabi v. The State (2001) 4 NWLR (Pt. 706) at 256.

Note 7. The right to kill in defence of property is confined, in the Criminal Code, to the right to kill a person who is attempting to break and enter a dwelling house in order to commit a felony in it (Section 282 of the Criminal Code). There is no right to kill in defence of other kinds of property. See Okonkwo C.O., "The Nigerian Penal System in 
the Light of the African Charter of Human Rights", in Kalu A.U. \& Osibanjo Y. (eds.) Vol. 12, Perspectives on Human Rights, 1992) 97.

Note 8. See n. 6 supra.

Note 9. See 1963 Constitution, s. 31; 1979 Constitution, s. 40; 1999 Constitution, s. 44. See also LSDPC v. Foreign Finance Corp. (1987) 1 NWLR (Pt. 50) 413; Obikoya v. Gov. Lagos State (1987)1 NWLR (Pt.49); African Continental Bank v. Okonkwo (1997) I NWLR (480) 197; Kanada v. Gov. Kaduna State (1986) 4 NWLR (Pt. 35); Ononuju v. Attorney, Anambra State (1998) 1 NWLR (Pt. 573) 309; Lawson v. Ajibulu (1997) 6 NWLR (Pt. 570) 14; Integrated Rubber Products v. Oviawe (1992) 5 NWLR (Pt. 243) 572; Nitel v. Ogunbiyi (1992) 7 NWLR (PT.255) 255.While section 33 of the 1963 Constitution used the phrase: "adequate compensation" sections 40 and 44 of the 1979 and 1999 Constitutions respectively use the words "prompt compensation." S. 43 of the 1999 Constitution, however, guarantees the "Right to acquire and own immovable property anywhere in Nigeria."

Note 10. Protocol to the Convention for the Protection of Human Rights and Fundamental Freedoms, 1950, Art. 1; Declaration of the Rights and Duties of Man, adopted by the $9^{\text {th }}$ Inter'l Conf. of American States 1948, Art. 23, Human \& Peoples' Rights, 1981 OAU Doc. CAB/LEG/67/3/Rev.5,21ILM58, Art. 14.

Note 11. Criminal Code, ss. $427 \&$ 430; Penal Code, ss. 316, 317, 319A.

Note 12. Criminal Code, ss. $427 \&$ 430; Penal Code, ss. 316, 317, 319A.

Note 13. Criminal Code, ss. 401, 402, 403 and 403A; Penal Code, ss. 296, 298-300, 303.

Note 14. Criminal Code, s. 410; Penal Code, ss. 345-346.

Note 15. Criminal Code, s. 421; Penal Code, s. 320.

Note 16. Penal Code, s. 291.

Note 17. Penal Code, s. 308.

Note 18. Criminal Code, ss. 98-106; Penal Code, ss. 115-131; Corrupt Practices and Other Related Offences Act, 2002; ss. 8-26.

Note 19. See generally Exodus 20.

Note 20. Id., Verse 15. (King James version).

Note 21. Genesis 44: 5.

Note 22. Joshua 22: 20.

Note 23. For some other provisions in the Holy Bible regarding stealing, see: Genesis 27:36; 1 Samuel 23:1; Matthew 19:18; Matthew 27:64; Luke 16:2; Roman 13:9; Ephesians 4:28 and 1 Peter 4:15.

Note 24. For discussions on Law and religion, see Elegido J. M., Jurisprudence (Ibadan: Spectrum Law Publishing, 2000), 367-312; Eso K., Thoughts on Law and Jurisprudence, 1990, 291- 305.

Note 25. Garner B.A. (ed.), Black's Law Dictionary ( $8^{\text {th }}$ edn., 2004), at 1453.

Note 26. Section 3 of the Criminal Code provides that: "A felony is any offence which is declared by law to be a felony, or is punishable, without proof of previous conviction, with death or with imprisonment for three years or more."

Note 27. Words in italics mine for emphasis.

Note 28. (1994) 8 NWLR (P. 364), at 599.

Note 29. Low v. Blease (1975) Crim. L.R. 513.

Note 30. Collins v. Director of Public Prosecution (1987) Times, 20 Oct.

Note 31. $R$ v. McCreadie and Tume (1992) 6 Cr. APP.R. 143.

Note 32. (2000) 12 NWLR (Pt. 682) 598.

Note 33. Ocheme P., supra n. 6 at 227.

Note 34. Words in italics mine for emphasis.

Note 35. Bone S (ed.), Osborn's Concise Law Dictionary $9^{\text {th }}$ edn., 2001, at 364; "Stealing. See Theft"; the meaning of "theft" as provided in page 376 of the dictionary is the provision of sections 1 and 7 of the English Theft Act 1968 as amended by s. 7 by the Criminal Justice Act 1991, s. 26(1).

Note 36 . With regard to stealing. 
Note 37. Onagoruwa v. State (1993) 7 NWLR (Pt. 303), 86.

Note 38. Id.

Note 39. Alaka v. State (1991) 7 NWLR (Pt. 215) 575 at 593 per Niki Tobi; Clark v. The State (1986) 4 NWLR (Pt. $35)$, at 381.

Note 40. Okonkwo and Naish, Criminal Law in Nigeria $\left(2^{\text {nd }}\right.$ edn., Ibadan : Spectrum Law Series, 2005) at 296.

Note 41. $R$ v. Nicholas Vega (1938) 4 WACA 8.

Note 42. Tijani v. Commissioner of Police (1994) 3 NWLR (Pt. 335), 695 at 703-704.

Note 43. Id.

Note 44. Fakayode E.O., The Nigerian Criminal Code Companion, 1985, at 27.

Note 45. Id., See for detailed discussions on "Ownership and Possession," See Dias Jurisprudence 5th edn., (London: Butterworths, 1985), at 272-304; Elegido J.M., supra n. 24 at 208-211.

Note 46. In Turner (No. 2) [1971] 1 WLR 901 (CA), the defendant was held to be guilty of theft for removing his car from outside a garage where it had undergone repair. It was reasoned that the garage was in possession of the car.

Note 47. Words in italics mine for emphasis.

Note 48. (1956) FSC 62.

Note 49. Chukkol K.S., supra n. 1, at 200.

Note 50. Ocheme P., supra n. 6 at 229.

Note 51. Sepulveda M. et al, Universal and Regional Human Rights Protection: Cases and Commentaries, at 375.

Note 52. Criminal Code, s. 1.

Note 53. English Theft Act, 1968, s. 4; Victoria Crimes Act 1958, s. 7 (1).

Note 54. (1902) KB 427 at 430.

Note 55. (1988) 1 WLR 196 PC.

Note 56. See Oxford v. Moss (1979) 68 Cr APP R 183 (DC).

Note 57. See $R$ v. Absolom, The Times, 14 Sept. 1983.

Note 58. Criminal Code, s. 390(3).

Note 59. Id., s. 371.

Note 60. English Theft Act, s. 4 (2).

Note 61. English Theft Act, s. 4 (2).

Note 62. Id.

Note 63. See Card R. (ed.), Cross \& Jones, Introduction to Criminal Law $9^{\text {th }}$ edn., 1980, at 206.

Note 64. English Theft Act, s. 4(2).

Note 65. Onaguruwa v. The State, Supra n.35 at 88. See also Mumuni v. The State (1975) 6 SC 77 at 88.

Note 66. Halbury's Laws of England, $6^{\text {th }}$ edn., at 58.

Note 67. Salmon, Salmon on Jurisprudence, $5^{\text {th }}$ edn., at 268.

Note 68. (1938) 1 All AER 48.

Note 69. (1996) All ER, 474.

Note 70. (1999) 2 WLR 384.

Note 71. Okonkwo and Naish, supra n. 40 at 296.

Note 72. (1908) 6 CLR 406.

Note 73. Supra note 69.

Note 74. The offence is punishable "with imprisonment which may extend to five years or fine or with both."

Note 75. Penal Code, s. 219. The offence is punishable "with imprisonment which may extend to five years or with fine or both. 
Note 76. Shodiya v. The State (1992) 2 NWLR (pt. 230) at 460 at 476.

Note 77. Mohammed v. The State, supra n. 32.

Note 78. (1970) 1 KB 74.

Note 79. Okonkwo and Naish, supra n. 40 at 288.

Note 80. See also Fakayode E.O., supra n. 44 at 27.

Note 81. (1971) 2 All ER 44.

Note 82. (1970) All ER 97.

Note 83. (1976) NWLR 150.

Note 84. Bone S., supra $\mathrm{n} .35$ at 106.

Note 85. Garner B.A. (ed.), supra n. 25 at 356. See also Atkins J. (as he then was) in Lancashire \& Yorkshire Railway Co. v. MacNicol (1919) 88 LJ KB 601 at 605. For detailed discussion on the tort of conversion see W.V.H. Roger (ed.), Winfield and Jolowicz on Tort $15^{\text {th }}$ edn., (London: Sweet \& Maxwell, 1998), at 588-611; Brazier M. \& Murphy J., (eds.), Street on Torts (10 ${ }^{\text {th }}$ edn., London: Butterworths, 1999), at 44-67; Kodilinye \& Aluko, The Nigerian Law of Torts, Revised edition (Ibadan: Spectrum Books Ltd., 1999), at 199-209; Nwoke F.C., Law of Torts in Nigeria, (Jos: Mono Expressions Ltd., 2003), at 71-83; Omotosho A., The Law of Tort in Nigeria: Selected Themes (Lagos: Malthouse Law Books, 2009) at 62-66; Fekumo J.F., "Measure of Damages for Conversion and Detenue in Nigeria - A Critical Review," in Ayua T.A. (ed.), Nigerian Current Legal Problems, Vol. 4 \& 5 (Lagos: Inst. of Advanced Leg. Stud., 1996-1998), 106-137. For Nigerian cases on Conversion see: Darefooh v. Karam (1989) 3 NWLR (Pt. 107) at 15, per Nnamani JSC; P.A. Oguigo \& Son Ltd. v. C.O.P. (1991) 3 NWLR (Pt. 177), 46 at 63, per Ejiwunmi JCA; Stitch v. Attorney-General, Federation (1986) 5 NWLR (Pt. 46) at 1033, per Uwais JSC (as he then was); Civil Design Construction Nig. Ltd. v. SCOA Nig. Ltd. (2007) 6 NWLR (Pt. 1030); Ihenacho v. Uzochukwu (1997) 2 NWLR (Pt. 487); Commissioner of Police \& Anor. v. Ogunbayo (1993) NWLR (Pt. 299); W.A. Oilfields Service Ltd. v. U.A.C. (Nig.) Ltd. (2000) 13 NWLR (Pt. 683); 7-up Bottling Co Ltd \& 2 Ors. v. Abiola \& Sons Bottling Co. Ltd (2001) 6 NSCQR 905.

Note 86. Garner B.A. (ed.), supra n. 25 at 356.

Note 87. (2006) 10 NWLR (Pt. 988) at 428, per Niki Tobi JCA (as he then was).

Note 88. The definition of Stealing in Black's Law Dictionary also uses the words: "Larceny, embezzlement and fraudulent." See Garner B.A. (ed.), supra n. 25.

Note 89. Supra, n. 28 at 602, per Kalgo JCA.

Note 90. R. v. Anyadiagwu (1984) 9 WACA 67.

Note 91. Criminal Code, s. 383(4).

Note 92. (1960) 5 FSC 105.

Note 93. See, for example, Alaka v. The State, supra note 39 at 593, per Niki Tobi JCA (as he then was); Ajiboye v. State, supra note 28 at 599, per Kalgo JCA; Ukanu v. Commissioner of Police (1995) 8 NWLR (Pt. 416), 709 at 722, per Ige JCA.

Note 94. (1961) All NLR 478 FSC.

Note 95. R. v. Turvey (1946) 2 ER 60; R v. Egginton (1801) 20.

Note 96. See Apamu v. The State (1997) 3 NWLR (Pt. 493), 289 CA. For detailed discussion on bona fide claim of rights, see Olajide - Bello A., "The Defence of Bona Fide Claim of Rights in Nigeria: An Appraisal”, Univ. of Ado-Ekiti Law Journal, Vol. 2, 2003, at 28-46.

Note 97. Criminal Code, s. 25, Penal Code, s. 45. See Chukkol K.S., supra n. 6 at 10-29.

Note 98. Chukkol K.S., supra note 1 at 200.

Note 99. Id, see also Oshinye v. Commissioner of Police, supra n. 92.

Note 100. Mohammed v. The State, supra n. 32, 603 at 604, per Omage JCA.

Note 101. See English Theft Act, s. 2(1). See also R v. Ghosh (1982) QB 1053 (CA); see also Victoria Theft Act 1958, s. 73 (2)(a) (b) (c).

Note 102. Penal Code, 16. 
Note 103. Id., s.13.

Note 104. Id., s. 14.

Note 105. Keffi Native Authority v. Alagbo (1960) NWLR 32.

Note 106. Onwudiwe v. Federal Republic of Nigeria, supra n. 87, at 429.

Note 107. Penal Code, s. 16.

Note 108. Criminal Code, s. 383(2)(a).

Note 109. Criminal Code, s. 383(2)(a).

Note 110. (1989) 4 NWLR (Pt. 115), at 270, per Karibi-Whyte. See also Ukanu v. Commissioner of Police, supra $\mathrm{n}$. 93 at 709 at 722 .

Note 111. Supra n. 28.

Note 112. English Theft Act, 1968, s. 6(1). See also Victoria Theft Act, 1958, s. 73 (12).

Note 113. Finch E. \& Stefan F., Criminal Law (2 $2^{\text {nd }}$ edn., England: Pearson Longman, 2009) at 177.

Note 114. Id., at 178. Note 115. See $R$ v. Barley (1924) Q. W. N. 38.

Note 116. For discussion on s.383 (2) (e) of the Criminal Code, See Okonkwo and Naish, supra n. 40 at 294.

Note 117. Supra n. 48. 